\title{
Profile of aerobic fitness and muscle power of athletes on the Brazilian National Paralympic Five-a-side Football Team
}

http://dx.doi.org/10.11606/1807-5509201900030345

\begin{abstract}
We aimed to profile the aerobic fitness and muscle power of five-a-side football athletes on the Brazilian National Paralympic Team. The sample consisted of 12 male Paralympic athletes on the Brazilian National five-a-side football team, including 3 sighted goalkeepers and 9 blind (B1 category) outfield players. The results were: peak oxygen uptake ( $\mathrm{VO}_{2}$ peak), $51.8 \pm 5.8 \mathrm{ml} / \mathrm{kg} / \mathrm{min}$; maximum speed, $17.1 \pm 1.4 \mathrm{~km} / \mathrm{h}$ and $\mathrm{VO}_{2}$ ventilatory threshold $(\mathrm{VT}), 40.2 \pm 6.5 \mathrm{ml} / \mathrm{kg} / \mathrm{min}$ The peak torque values $(\mathrm{Nm})$ of the right and left legs were $241 \pm 48$ and $234 \pm 45$ for $60^{\circ}$ extension, $127 \pm 17$ and $123 \pm 16$ for $60^{\circ}$ flexion, $170 \pm$ 29 and $162 \pm 28$ for $180^{\circ}$ extension, $113 \pm 13$ and $109 \pm 13$ for $180^{\circ}$ flexion, $130 \pm 20$ and $129 \pm 23$ for $300^{\circ}$ extension, and $118 \pm 17$ and $115 \pm 18$ for $300^{\circ}$ flexion, respectively. The five-a-side football players on the Brazilian National Paralympics Team exhibited physiologically normal responses to physical training related to the observed physical capacities as shown by the aerobic fitness and muscle power results observed. These results suggest that blind individuals can improve their physical capacity regardless of their visual impairment.
\end{abstract}

KeYwords: Paralympics Athletes; Aerobic Fitness; Muscle Power.

\section{Introduction}

The Paralympics have grown considerably in recent years and are considered the most important sports event for people with disabilities ${ }^{1}$. Five-aside football is an adaptation of futsal for visually impaired athletes that uses the rules of futsal but includes changes in the game field, equipment and number of players, amongst others, to make the game suitable for visually impaired athletes ${ }^{2}$.

Studies have shown that sedentary individuals with visual impairments can exhibit compromised cardiorespiratory fitness and muscle power compared with healthy individual $s^{3}$. Comparisons between subjects with and without visual impairments suggest lower performance of individuals with visual impairments in both motor performance and physical fitness ${ }^{4}$.
There are several possible explanations for their reduced levels of physical fitness such as parental restrictive behaviour, the availability of different types of physical activities and neuroendocrine changes due to less light exposition ${ }^{4}$. KILLEBREW et al. ${ }^{5}$ showed that untrained individuals exhibited poorer performance on a strength test when they were blindfolded. However, a strength-training programme was found to attenuate the poor performance of blindfolded individuals $s^{5}$. In other words, strength-training interventions may be successful in protecting individuals from losses in muscle power when visual input is removed ${ }^{5}$.

Five-a-side football is a sport characterised by intermittent activity, that is, high-intensity activity with short recovery periods over a total 
time of 50 minutes, divided into two 25 -minute periods $s^{6}$. Accordingly, five-a-side football players require high aerobic fitness to practise this sport at a high level, given the energy demands of the game and the short recovery time. Within this context, it is important to assess the aerobic fitness of five-a-side football athletes because this physical quality is essential for high performance in this sport ${ }^{7}$. In addition to aerobic fitness, muscle power is another important physical capability for the practise of five-a-side football. When training in this sport, athletic gestures such as kicking, jumping, running and changing pace, among others, demand sufficient physical capability (power), which is essential for this sport ${ }^{8}$. Furthermore, injuries may result from the lack of strength in the ischiotibial and quadriceps

\section{Method}

\section{Participants}

The sample in the present study consisted of 12 healthy male Paralympic athletes on the Brazilian national five-a-side football team, including 3 goalkeepers (normal sight) and 9 blind (B1 category) whose demo-graphic data, presented as the mean (SD), were as follows: age $25.8 \pm$ (5.6) years; height $174 \pm(7.1) \mathrm{cm}$; weight $73.8 \pm(7.9) \mathrm{kg}$; body mass index (BMI) $24.12 \pm$ (2.5); $\left(\mathrm{kg} / \mathrm{m}^{2}\right)$ and body fat $14.1 \pm 4.8 \%$.

\section{Procedures}

The present study was approved by the Research Ethics Committee of the Federal University of São Paulo (CEP 0294/11). All of the volunteers signed an informed consent form before starting this protocol, and their participation in the study was of their own free will and accord.

The volunteers visited the Centre for Psychobiology and Exercise Studies over 3 consecutive days. On the first day, the athletes were subjected to a body composition evaluation and an electrocardiogram (ECG) at rest and during exertion. On the second day, an ergospirometric test consisting of an aerobic evaluation was performed, followed by an isokinetic dynamometry evaluation on the third muscles and/or deficits in the bilateral ratio and ischiotibial/quadriceps (I/Q) ratio combined with the high physical demands of the game.

Thus, it is important to assess the aerobic fitness and muscle power of five-a-side football athletes to evaluate the profile of such physical capabilities in this population and to provide normative values for the sport. Furthermore, we believe that visually impaired individuals who undergo physical training will show values for the above capabilities within the normal range for non-disabled athletes, thus demonstrating that blind athletes can adapt to the demands of physical training. Therefore, the objective of the present study was to evaluate the aerobic fitness and muscle power of five-a-side football athletes on the Brazilian National Paralympic Team.

day. All tests were performed at the same time of the day (at the beginning of the afternoon period) to avoid the circadian variation impact on performance. There was no control over diet and Paralympics athletes continued with their eating routines.

\section{Body composition assessment}

The measurement device (BodPod ${ }^{\circledR}$, Life Measurement Instruments, Concord, CA, USA) consists of two closed chambers separated by a diaphragm that records changes in the pressure and volume between the chambers. The volunteers used minimal clothing and a cap to minimise the effects of isothermal air to accurately assess body volume. Specifically, the volunteers remained seated in the test chamber to assess body volume, which was repeated 2 or 3 times. Shortly thereafter, the thoracic gas volume was collected through a specific breathing process (3 gentle puffs). After this procedure, the device measured the body density of the volunteers, and then the Siri's equation was used to calculate the per cent body fat ( $\%$ fat) of each volunteer ${ }^{9}$.

\section{Ergospirometric assessment}

An incremental treadmill test (Life Fitness $\left.9500 \mathrm{HR}^{\circledR}, \mathrm{USA}\right)$ at a speed of $6 \mathrm{~km} / \mathrm{h}$ for 3 
minutes and with an increase of $1 \mathrm{~km} / \mathrm{h} / \mathrm{min}$ until maximal volitional exhaustion was performed to determine the following respiratory variables: peak oxygen uptake $\left(\mathrm{VO}_{2}\right.$ peak) and ventilatory threshold (VT). Maximum volitional exhaustion was determined based on the volunteer's report of muscle fatigue, general fatigue, muscle or joint soreness, $\mathrm{VO}_{2}$ plateau $\left(\leq 150 \mathrm{ml} \mathrm{min}^{-1}\right)$, attainment of the percentage of the age-predicted maximal HR (HRpeak) within \pm 5 beats $\min ^{-1}$ , respiratory exchange ratio $\geq 1.10$ or the loss of the coordination required to maintain the treadmill pace' ${ }^{9}$. A gas analyser (Cosmed QUARK PFTergo ${ }^{\circledR}$, Rome, Italy) was used to determine respiratory variables, including peak $\mathrm{VO}_{2}$, VT1 and VT2. Peak $\mathrm{VO}_{2}$ was estimated based on the highest relative $\mathrm{VO}_{2}\left(\mathrm{ml} \mathrm{kg}^{-1} \mathrm{~min}^{-1}\right)$ obtained at the end of the test. Peak heart rate was the highest value during test. VT1 and VT2 were assed the criteria described by WASSERMAN AND KOIKE ${ }^{10}$.

The system was calibrated prior of each assessment, using a known gas concentration, and volume and flow calibrations were performed using a three-liters syringe. A Hans Rudolph ${ }^{\circledR}$ face-mask mask (Kansas City, MO, USA) was used and during all tests, the heart rate was monitored by Polar heart rate monitor (Polar ${ }^{\circledR}$, Advantage NV model) with intervals of 5 seconds. All procedure were performed in a laboratory with standard air conditioning $\left(20^{\circ} \mathrm{C}\right.$ \pm 2 and air humidity in $55 \% \pm 2$ ).

\section{Muscle power evaluation}

Muscle power evaluation was performed using the computer-based Biodex System 3

\section{Results}

TABLE 1 shows the means and minimum and maximum values of the cardiorespiratory profiles of the five-a-side football athletes on the Brazilian National Paralympic Team. The following cardiorespiratory values were found for the athletes: $\mathrm{VO}_{2}$ peak, $51.8 \pm 5.8 \mathrm{ml} / \mathrm{kg} / \mathrm{min}$; maximum speed, $17.1 \pm 1.4 \mathrm{~km} / \mathrm{h} ; \mathrm{VO}_{2} \mathrm{VT} 1$, $40.2 \pm 6.5 \mathrm{ml} / \mathrm{kg} / \mathrm{min}$; Maximum Heart Rate VT1 $167.2 \pm 10.2 \mathrm{bpm}$; Maximum Speed VT1 $11.1 \pm 1.1 \mathrm{~km} / \mathrm{h} ; \mathrm{VO}_{2} \mathrm{VT} 2,48.6 \pm 5.7 \mathrm{ml} / \mathrm{kg} /$
Pro ${ }^{\circledR}$ isokinetic dynamometer (Biodex Medical Systems, Shirley, NY, USA), which has been previously validated by Drouin et al. ${ }^{11}$.

Tests were conducted at 3 speeds according to the parameters of GoŁEBIEWSKA, MASTALERZ AND ZIELIŃSKI ${ }^{12}: 60 \%$ for 5 repetitions, $180 \%$ s for 10 repetitions, and $300 \%$ for 15 repetitions. The volunteers were instructed to exert maximum power and were given a 1-min rest between cycles $^{13}$. All of the volunteers warmed up for 5 min on an ergometric bicycle before the beginning of the evaluation. The athletes were familiarised with each speed and performed a submaximal strength test before each evaluation.

A single trained evaluator was responsible for all of the tests and used standardised verbal commands. He allowed the volunteers to see the nominal torque curve on the display during the evaluation for visual feedback when possible. The analysed data were peak torque $(\mathrm{Nm})$ and total work $(\mathrm{J})$. The peak torque data were used to evaluate the muscle power of the knee flexors and extensors. The peak torque ratio between the I/Q muscles and the bilateral deficit (per cent difference of peak torque between the left and right limbs) was used to evaluate the athletes' muscle balance.

\section{Statistical analysis}

A descriptive analysis was conducted using the mean \pm standard deviation together with the maximum and minimum values of all of the examined variables. Descriptive analyses were performed using the Statistica ${ }^{\circledR}$ software 7.0 (StatSoft, Inc.). min; Maximum Heart Rate VT2 $184.0 \pm 7.5$ bpm; Maximum Speed VT2 () $14.7 \pm 1.3 \mathrm{~km} / \mathrm{h}$; \%VT1 $\mathrm{VO}_{2}, 72.7 \pm 21.7$; and $\% \mathrm{VT} 2 \mathrm{VO}_{2}, 93.9 \pm 5.2$.

TABLE 2 shows the means and minimum and maximum values of muscle power capacity of five-a-side football athletes on the Brazilian National Paralympic Team.

TABLE 3 shows the means and minimum and maximum values of the $\mathrm{I} / \mathrm{Q}$ ratios of the right and left legs. 
Results are expressed as the mean \pm standard deviation and range for 12 five-a-side football athletes. Abbreviations: $\mathrm{VO}_{2}$ Peak $=$ peak oxygen uptake; bpm = beats per minute; $\mathrm{km} / \mathrm{h}=$ kilometres per hour; VT = ventilator threshold.

TABLE 1 - Cardiorespiratory variables for five-a-side football athletes on the Brazilian National Paralympic Team

\begin{tabular}{|c|c|c|}
\hline Variables & Mean \pm SD & (Range) \\
\hline $\mathrm{VO}_{2}$ Peak $(\mathrm{ml} / \mathrm{kg} / \mathrm{min})$ & $51.8 \pm 5.8$ & $(39.3-61.3)$ \\
\hline Predicted Maximum Heart Rate (bpm) & $194.0 \pm 5.8$ & $(183-204)$ \\
\hline Maximum Heart Rate (bpm) & $190.4 \pm 7.5$ & $(177-203)$ \\
\hline Maximum Speed Test (km/h) & $17.1 \pm 1.4$ & $(15-20)$ \\
\hline $\mathrm{VO}_{2} \mathrm{VT} 1(\mathrm{ml} / \mathrm{kg} / \mathrm{min})$ & $40.2 \pm 6.5$ & $(29.4-50.78)$ \\
\hline Maximum Heart Rate VT1 (bpm) & $167.2 \pm 10.2$ & $(150-183)$ \\
\hline Maximum Speed VT1 (km/h) & $11.1 \pm 1.1$ & $(9-13)$ \\
\hline $\mathrm{VO}_{2} \mathrm{VT} 2(\mathrm{ml} / \mathrm{kg} / \mathrm{min})$ & $48.6 \pm 5.7$ & $(34.9-56.4)$ \\
\hline Maximum Heart Rate VT2 (bpm) & $184.0 \pm 7.5$ & $(173-198)$ \\
\hline Maximum Speed VT2 (km/h) & $14.7 \pm 1.3$ & $(12-17)$ \\
\hline$\% \mathrm{VO}_{2} \mathrm{VT} 1$ & $72.7 \pm 21.7$ & $(63-93)$ \\
\hline$\% \mathrm{VO}_{2} \mathrm{VT} 2$ & $93.9 \pm 5.2$ & $(82-100)$ \\
\hline
\end{tabular}

TABLE 2 - Muscle power capacity of Paralympic five-a-side football athletes.

Results are expressed

as the mean \pm stan-

dard deviation and range (minimum and maximum) for 12 five-a-side football athletes. Abbreviations: $\mathrm{Nm}=$ Newton*meter; $\mathrm{J}=$ joules; $\mathrm{BD}=$ bilateral difference in peak torque

\begin{tabular}{|c|c|c|c|c|c|c|c|c|}
\hline Variables & Right & (Range) & Left & (Range) & Right & (Range) & Left & (Range) \\
\hline & \multicolumn{4}{|c|}{ Extension $60^{\circ} / \mathrm{s}$} & \multicolumn{4}{|c|}{ Flexion $60^{\circ} / \mathrm{s}$} \\
\hline $\begin{array}{l}\text { Peak } \\
\text { Torque } \\
\text { (Nm) }\end{array}$ & $241 \pm 48$ & $\begin{array}{l}(189.8- \\
325.7)\end{array}$ & $234 \pm 45$ & $\begin{array}{l}(197.4- \\
310.10)\end{array}$ & $127 \pm 17$ & $\begin{array}{c}(108.5- \\
147.7)\end{array}$ & $123 \pm 16$ & $(97.3-142)$ \\
\hline $\begin{array}{l}\text { Total } \\
\text { Work (J) }\end{array}$ & $921 \pm 204$ & $\begin{array}{c}(707.9 \\
-1210.5)\end{array}$ & $871 \pm 224$ & $\begin{array}{l}(636.8- \\
1230.8)\end{array}$ & $586 \pm 87$ & $\begin{array}{c}(493.2- \\
716)\end{array}$ & $555 \pm 111$ & $\begin{array}{l}(395.1 \text { - } \\
728.9)\end{array}$ \\
\hline \multirow[t]{2}{*}{$\mathrm{BD} \%$} & \multicolumn{2}{|c|}{$5.4 \pm 6.1$} & \multicolumn{2}{|c|}{$1.1-17.6$} & \multicolumn{2}{|c|}{$6.5 \pm 6.2$} & \multicolumn{2}{|c|}{$0.6-16.6$} \\
\hline & \multicolumn{4}{|c|}{ Extension $180^{\circ} / \mathrm{s}$} & \multicolumn{4}{|c|}{ Flexion $180^{\circ} / \mathrm{s}$} \\
\hline $\begin{array}{l}\text { Peak } \\
\text { Torque } \\
(\mathrm{Nm})\end{array}$ & $170 \pm 29$ & $\begin{array}{l}(141.3- \\
213.5)\end{array}$ & $162 \pm 28$ & $\begin{array}{l}(132.6- \\
200.4)\end{array}$ & $113 \pm 13$ & $\begin{array}{l}(96.5- \\
129.9)\end{array}$ & $109 \pm 13$ & $(93.9-131)$ \\
\hline $\begin{array}{l}\text { Total } \\
\text { Work (J) }\end{array}$ & $1427 \pm 274$ & $\begin{array}{c}(1110.1 \text { - } \\
1801.7)\end{array}$ & $1375 \pm 270$ & $\begin{array}{l}(1086.8 \\
1807.1)\end{array}$ & $904 \pm 109$ & $\begin{array}{l}\text { (798.7 - } \\
1077.5)\end{array}$ & $874 \pm 89$ & $\begin{array}{c}(761.3- \\
1011)\end{array}$ \\
\hline \multirow[t]{2}{*}{ BD $\%$} & \multicolumn{2}{|c|}{$4.4 \pm 1.9$} & \multicolumn{2}{|c|}{$1.5-6.2$} & \multicolumn{2}{|c|}{$6.9 \pm 5$} & \multicolumn{2}{|c|}{$0.9-14.5$} \\
\hline & \multicolumn{4}{|c|}{ Extension $300^{\circ} / \mathrm{s}$} & \multicolumn{4}{|c|}{ Flexion $300^{\circ} / \mathrm{s}$} \\
\hline $\begin{array}{l}\text { Peak } \\
\text { Torque } \\
(\mathrm{Nm})\end{array}$ & $130 \pm 20$ & $\begin{array}{c}(110.7 \text { - } \\
159)\end{array}$ & $129 \pm 23$ & $(103-164)$ & $118 \pm 17$ & $(94-137)$ & $115 \pm 18$ & $(09-141)$ \\
\hline $\begin{array}{l}\text { Total } \\
\text { Work (J) }\end{array}$ & $1524 \pm 140$ & $\begin{array}{c}(1377.1 \text { - } \\
1734)\end{array}$ & $1543 \pm 228$ & $\begin{array}{l}(1232- \\
1892.3)\end{array}$ & $1037 \pm 113$ & $\begin{array}{l}(926.3- \\
1242.9)\end{array}$ & $1064 \pm 84$ & $\begin{array}{l}(954.4- \\
1203.7)\end{array}$ \\
\hline $\mathrm{BD} \%$ & \multicolumn{2}{|c|}{$5 \pm 3.6$} & \multicolumn{2}{|c|}{$1.8-11.5$} & \multicolumn{2}{|c|}{$4.4 \pm 2.6$} & \multicolumn{2}{|c|}{$1.6-7.7$} \\
\hline
\end{tabular}

TABLE 3 - I/Q ratio of five-a-side Paralympic football athletes

\begin{tabular}{ccccc}
\hline & Right leg & (Range) & Left leg & (Range) \\
\hline I/Q 60 & $44.8 \pm 20.2$ & $(5-58)$ & $53.1 \pm 10.9$ & $(40-71)$ \\
I/Q 180 & $67 \pm 8.6$ & $(56-82)$ & $67.1 \pm 11.5$ & $(51-82)$ \\
I/Q 300 & $85.6 \pm 5$ & $(79-91)$ & $87.1 \pm 9.5$ & $(71-97)$ \\
\hline
\end{tabular}




\section{Discussion}

Five-a-side football is a Paralympic sport that requires good aerobic fitness and muscle power when played at a high level, given its energy demands and high intensity. Thus, our data showed that the physical training practised by visually impaired athletes on the Brazilian national five-a-side football team may lead to improved aerobic fitness and muscle power, regardless of their visual deficit, corroborating the data of KILLEBREW et al. 5 .

The similarity between five-a-side football and futsal may help with the evaluation of the results from the present study, given that there are few studies on five-a-side football. Accordingly, a study conducted by CASTAGNA et al. ${ }^{14}$ showed that heart rate during a professional futsal match exhibited high-intensity characteristics, i.e., the players worked at a range between $75 \%$ and $90 \%$ of their $\mathrm{VO}_{2}$ peak during most of the match, with short breaks during which the athlete could show a partial recovery ${ }^{14}$. Accordingly, the identification of the $\mathrm{VO}_{2}$ peak and VT may help coaches plan training sessions, given that five-a-side football shows a physiological demand similar to that of futsal due to the similarities between the two sport disciplines.

The present study showed that the mean $\mathrm{VO}_{2}$ peak values and respiratory variables including maximum speed, $\% \mathrm{VO}_{2}$ peak in $\mathrm{VT}$, and treadmill speed at VT1were similar to semi-professional and professional futsal players during a cardiopulmonary test ${ }^{15}$. In view of these similarities, BERNARDI et al. ${ }^{16}$ argued that it is important to conduct field tests with Paralympic athletes, accounting for the site where the sport is practised and the type of disability ${ }^{16}$. It is possible that a mean $\mathrm{VO}_{2}$ peak value close to the values for professional athletes reported by ALVAREZ et al. ${ }^{15}$ could be found in a five-a-side football field test ${ }^{15}$. This could occur given the sport's specificities and because blind athletes feel safer in field assessments.

In addition to $\mathrm{VO}_{2}$ peak, VTs as measured by ergospirometry are excellent markers for controlling the intensity at which the physical training is being conducted $^{17}$. The assessment of the intensity of physical exercise based on the VT is more efficient for improving cardiorespiratory fitness ${ }^{18}$, because these thresholds determine the specific metabolic phases during progressive physical exercise ${ }^{19}$. Such measurements may accurately reflect the metabolic stress experienced by the athletes during the ergospirometric test in the present study.

The data from the present study showed that VT1 and VT2 reached approximately $73 \%$ to $94 \%$ of $\mathrm{VO}_{2}$ peak, respectively, which were ideal for aerobic training in the evaluated athletes. In this context, AZEVEDO et al. ${ }^{20}$ showed that men without physical or visual disabilities and with high cardiorespiratory fitness who participated in races had a VT1 and VT2 interval between $78 \%$ and $93 \%$, which may reflect good physical conditioning. In view of these findings, the physical conditioning of the visually impaired athletes observed in the present study is clearly similar to individuals with no disability ${ }^{20}$.

The evaluation of muscle power performed using isokinetic dynamometry provides normative data for muscle performance that may be useful in the prevention of and recovery from injury ${ }^{21}$. For visually impaired individuals, physical quality and muscle power are essential for the maintenance of postural stability, the correction of body sway, and balance recovery, in addition to preventing falls in everyday life ${ }^{5,22}$.

According to HonvaT et al. ${ }^{3}$, blind individuals may have lower muscle power than sighted individuals. Conversely, the torque values obtained for the blind athletes in the present study are higher than the results reported in the study mentioned above ${ }^{3}$. This difference in muscle performance for athletes on the Brazilian national five-a-side football team may be associated with the high physical demands imposed by the practise of professional football, which reflects better physical conditioning.

In this case, not only the sport itself but also the necessary training to prepare the athlete for the game, including strength training, may explain the better performance of these athletes in the test compared to the population in general 5 .

MAGNO et al. ${ }^{23}$ have evaluated the incidence of injuries in five-a-side football Paralympic athletes, observing an $80 \%$ rate of traumatic injuries and a $20 \%$ rate repetitive stress injuries, with $80 \%$ of the injuries occurring in the lower limbs ${ }^{23}$. Reinforcing this finding, a recent epidemiological study conducted during the London Paralympic Games showed that five-a-side football is the sport with the highest rate of incidence of injuries -22.4 injuries/1000 athlete-days ${ }^{24}$. Sports like five-a-side football tend to have more physical contact than other sports, including athletics and swimming, which show high indexes of injuries from repetitive stress ${ }^{23,25}$.

In an review of the literature, INKLAAR ${ }^{26}$ showed that the main changes considered to be injury risk factors in outdoor football athletes are asymmetries in the 
parameters of muscle power between the dominant and non-dominant limb and changes in the ratio of torque between agonist and antagonist muscles ${ }^{26}$.

No changes greater than $15 \%$ were found in the present study at any speed with respect to a bilateral deficit. This fact shows that five-a-side football athletes have a satisfactory muscle balance between their left and right leg muscles ${ }^{27}$. Curiously, these athletes showed noticeable muscle imbalances in the present study when evaluating the I/Q ratios, regardless of the speed of the movement $\mathrm{t}^{28}$.

In another study, Tomomitsu et al. ${ }^{29}$ aimed to assess the effect of reduced visual information on postural control in subjects with low vision and in sighted adults. Individuals with low vision had worse postural stability than individuals with normal vision on dynamic and balance tests under similar conditions ${ }^{29}$. The authors suggested that visual feedback was crucial for balance, especially for dynamic tasks (TOMOMITSU et al. $)^{29}$. Additionally, MoHAPATRA, KRISHNAN AND
ARUIN ${ }^{30}$ showed the importance of using visual cues for anticipatory and compensatory neural adjustments, which are crucial during the performance of many activities that demand the maintenance of a vertical posture $^{30}$. These factors may change the harmonic development of lower limb muscles in this group of athletes.

The establishment of normative data for the capacities for torque, work, and power production in professional five-a-side football players may substantiate clinical practise and support other scientific research studies.

In conclusion, in assessing the aerobic fitness and muscle power of five-a-side football players, the Brazilian National Paralympic Team showed physiologically normal responses to physical training. These results suggested that blind individuals presents capabilities within the normal range for non-disabled athletes and might improve their physical abilities despite their visual impairment.

\section{Acknowledgements}

We offer our thanks to the National Council for Scientific and Technological Development (Conselho Nacional de Desenvolvimento Científico and Tecnológico - CNPq), the Centres of Research, Innovation and Dissemination of the Sleep Institute (Centros de Pesquisa, Inovação e Difusão do Instituto do Sono - CEPID/SONO), the São Paulo Research Foundation (Fundação de Amparo à Pesquisa do Estado de São Paulo - FAPESP), the Federal University of São Paulo (Universidade Federal de São Paulo - UNIFESP), the Psychobiology and Exercise Research Centre (Centro de Estudos em Psicobiologia e Exercício - CEPE), the Multidisciplinary Centre for the Study of Drowsiness and Accidents (Centro de Estudo Multidisciplinar em Sonolência e Acidentes - CEMSA), and Professor Dr. Ronaldo Vagner Thomathieli dos Santos for his full review of the manuscript.

\section{Resumo}

Perfil da capacidade aeróbica e força muscular de atletas da seleção brasileira paralimpica de futebol de 5

Nosso objetivo foi avaliar a capacidade aeróbica e a força muscular dos atletas de futebol de cinco da Equipe Paralímpica brasileira. A amostra foi constituída por 12 atletas paralimpicos masculinos da equipe nacional de futebol de 5, incluindo 3 goleiros e 9 jogadores cegos (categoria B1). Os resultados foram: pico do consumo de oxigênio (pico de $\mathrm{VO}_{2}$ ), $51,8 \pm 5,8 \mathrm{ml} / \mathrm{kg} / \mathrm{min} ;$ Os valores de pico de torque (Nm) das pernas direita e esquerda foram $241 \pm 48$ e $234 \pm 45$ para a extensão de $60^{\circ}, 127 \pm 17$ e $123 \pm 16$ para flexão de $60^{\circ}, 170 \pm 29$ e $162 \pm 28$ para extensão de $180^{\circ}, 113 \pm 13$ e $109 \pm 13$ para flexão de $180^{\circ}$, $130 \pm 20$ e $129 \pm 23$ para extensão de $300^{\circ}$ e $118 \pm 17$ e $115 \pm 18$ para flexão de $300^{\circ}$, respectivamente. Os jogadores de futebol de 5 da equipe paralímpica brasileira apresentaram respostas fisiologicas normais frente ao treinamento físico relacionado às capacidades físicas observadas, conforme demonstrado pela capacidade aeróbia e os resultados de potência muscular observados. Estes resultados sugerem que indivíduos cegos podem melhorar sua capacidade física, independentemente de sua deficiência visual.

PalavRAS-Chave: Paralimpicos; Capacidade Aeróbica; Força Muscular. 


\section{References}

1. Thompson WR, Vanlandewijck YC. Science and the paralympic movement. Br J Sports Med. 2013;47:811.

2. IPC - International Paralympic Committee [homepage on the Internet]. Bonn, Germany: IPC; 1989. Football 5-a-side [cited 2017 Feb 12]. Available from: http://www.paralympic.org/sport/football-5-side.

3. Horvat M, Ray C, Nocera J, Croce R. Comparison of isokinetic peak force and power in adults with partial and total blindness. Percept Mot Skills. 2006;103:231-7.

4. Skaggs S, Hooper C. Individuals With Visual Impairments: A Review of Psychomotor Behavior Adapted Physical Activity Quarterly. J Hum Kinet. 1996;13;16-26.

5. Killebrew SS, Petrella JK, Jung AP, Hensarling RW. The effect of loss of visual input on muscle power in resistance trained and untrained young men and women. J Strength Cond Res. 2013;27:495-500.

6. De Mello MT, Winckler C. Esporte Paralímpico. Rio de Janeiro: Editora Atheneu; 2012.

7. O'Reilly J, Wong SH. The development of aerobic and skill assessment in soccer. Sports Med. 2012;42:1029-40.

8. Reilly T, Thomas V. A motion analysis of work-rate in different positional roles in professional football match-play. J Hum Mov Stud. 1976;2:87-89.

9. Howley ET, Bassett DR, Welch HG. Criteria for maximal oxygen uptake: review and commentary. Med Sci Sports Exerc. 1995;27:1292-1301.

10. Wasserman K, Koike A. Is the anaerobic threshold truly anaerobic? Chest. 1992;101(5 Suppl):211S-218S.

11. Drouin JM, Valovich-mcLeod TC, Shultz SJ, Gansneder BM, Perrin DH. Reliability and validity of the Biodex system 3 pro isokinetic dynamometer velocity, torque and position measurements. Eur J Appl Physiol. 2004;91:22-9.

12. Gołebiewska JA, Mastalerz A, Zieliński JR. Isokinetic muscle torque during glenohumeral rotation in dominant and nondominant limbs. Acta Bioeng Biomech. 2008;10:69-73.

13. Bayios IA, Anastasopoulou EM, Sioudris DS, Boudolos K.D. Relationship between isokinetic strength of the internal and external shoulder rotators and ball velocity in team handball. J Sports Med Phys Fitness. 2001;41:229-35.

14. Castagna C, D'Ottavio S, Granda VJ, Barbero AJC. Match demands of professional Futsal: a case study. J Sci Med Sport. 2009;12(4):490-4.

15. Alvarez JC, D'Ottavio S, Vera JG, Castagna C. Aerobic fitness in futsal players of different competitive level. J Strength Cond Res. 2009;23:2163-6.

16. Bernardi M, Guerra E, Di Giacinto B, Di Cesare A, Castellano V, Bhambhani Y. Field evaluation of paralympic athletes in selected sports: implications for training. Med Sci Sports Exerc. 2010;42:1200-8.

17. Swain DP, Abernathy KS, Smith CS, Lee SJ, Bunn SA. Target heart rates for the development of cardiorespiratory fitness. Med Sci Sports Exerc. 1994;26:112-116.

18. Dwyer J, Bybee R. Heart rate indices of the anaerobic threshold. Med Sci Sports Exerc. 1983;15:72-6.

19. Faria EW, Parker DL, Faria IE. The science of cycling: Factors affecting performance - part 2. Sports Medicin. 2005;35:313-337.

20. Azevedo LF, Perlingeiro PS, Brum PC, Braga AM, Negrão CE, de Matos LD. Exercise intensity optimization for men with high cardiorespiratory fitness. J Sports Sci. 2011;29:555-61.

21. Kannus P. Isokinetic evaluation of muscular performance: implications for muscle testing and rehabilitation. Int J Sports Med. 1994;15:11-8.

22. Horvat M, Ray C, Croce R, Blasch B. Comparison of isokinetic muscle strength and power in visually impaired and sighted individuals. Isokinet Exerc Sci. 2004;12(3):179-183.

23. Magno E, Silva MP, Winckler C, Costa E, Silva AA, Bilzon J, Duarte E. Sports injuries in paralympic track and field athletes with visual impairment. MedSci Sports Exer. 2013;45:908-13.

24. Willick SE, Webborn N, Emery C, Blauwet CA, Pit-Grosheide P, Stomphorst J, et al. The epidemiology of injuries at the London 2012 Paralympic Games. Br J Sports Med. 2013;47:426-32.

25. Silva MM, Bilzon J, Duarte E, Gorla J, Vital R. Sport injuries in elite paralympic swimmers with visual impairment. J Athl Train. 2013;48:493-8.

26. Inklaar H. Soccer Injuries I: A etiology and Prevention. Sports Med. 1994;18:81-93. 
Alves ES, et al.

27. Brown L. Isokinetics in Human Performance. Champaign, IL: Human Kinetics; 2000.

28. Calmels P, Minaire P. A Review of the role of the agonist/antagonist muscle pairs ratio in rehabilitation. Disabil Rehabil. 1995; 17:265-276.

29. Tomomitsu MS, Alonso AC, Morimoto E, Bobbio TG, Greve JM. Static and dynamic postural control in low-vision and normal-vision adults. Clinics. 2013;68:517-21.

30. Mohapatra S, Krishnan V, Aruin AS. The effect of decreased visual acuity on control of posture. Clin Neurophysiol. 2012;123:173-82.

CORRESPONDING AUTHOR:

Marco Túlio de Mello

Av. Presidente Carlos Luz, 4664 - Pampulha

Belo Horizonte - MG - BRASIL

CEP: 31.310 .250

E-mail: tmello@demello.net.br
Submitted: 21/02/2017

1st. Review: 22/05/2017

2nd. Review: 04/09/2017

Accepted: 20/09/2017

352 • Rev Bras Educ Fís Esporte, (São Paulo) 2019 Jul-Set; 33(3):345-52 